ISSN: $1412-1212$

\title{
THE Llfinniners
}

Economic, Business, Management, and Information System Journal

Volume 7, Nomor 2, September 2006

\begin{tabular}{|c|c|}
\hline \multicolumn{2}{|c|}{ Subcenter Publikasi Ilmiah bidang Ekonomi Universitas Bina Nusantara } \\
\hline Pelindung & Prof. Dr. Gerardus Polla, M.App.Sc. \\
\hline Redaktur Utama & Parulian Sihotang, Ak., M.Acc., Ph.D. \\
\hline Dewan Redaksi & $\begin{array}{l}\text { Antonius Herusetya S.E., M.M., Ak. } \\
\text { Misbahul Munir, Ak., MBA } \\
\text { Ir. Harjanto Prabowo, M.M. }\end{array}$ \\
\hline Mitra Bestari & $\begin{array}{l}\text { Dr. Hekinus Manao, M.Acc., C.G.F.M. } \\
\text { (Universitas Indonesia) } \\
\text { Dr. Sudarwan, M.B.A., Q.I.A. } \\
\text { (Universitas Trisakti) } \\
\text { Dr. Ir. Roy Sembel, M.B.A. } \\
\text { (Program Pascasarjana Universitas Bina Nusantara) } \\
\text { Edi Timbul Hardiyanto, S.E., Ak., M.Sc., M.B.A., B.A.P } \\
\text { (Institut Pendidikan Internal Auditor Indonesia) } \\
\text { Dr. Suroso Isnandar, M.Sc. } \\
\text { (University of Abertay, United Kingdom) } \\
\text { Marien Van Den Boom, Ph.D. } \\
\text { (In Holland University, The Netherlands) }\end{array}$ \\
\hline Editor & $\begin{array}{l}\text { Dra. Endang Ernawati, M.Lib. } \\
\text { Titik Rahayu S., S.S. }\end{array}$ \\
\hline Sekretariat & $\begin{array}{l}\text { Hery H.M., S.Kom. } \\
\text { Holil } \\
\text { Angga Ferdiansyah }\end{array}$ \\
\hline Alamat Sekretariat & $\begin{array}{l}\text { Subcenter Publikasi Ilmiah Bidang Ekonomi, } \\
\text { Center for Research and Comunnity Services, } \\
\text { Universitas Bina Nusantara } \\
\text { Jl. Kemanggisan Ilir III No. 45, Kemanggisan/ Palmerah, } \\
\text { Jakarta Barat } 11480 \\
\text { Telp.(021)5327630 ext. 6129 Fax. (021) 5300244 } \\
\text { e-mail: heryhm@binus.ac.id }\end{array}$ \\
\hline ISSN & $1412-1212$ \\
\hline
\end{tabular}


ISSN: $1412-1212$

THE Uhingnens

Economic, Business, Management, and Information System Journal

Volume 7, Nomor 2, September 2006

\section{DAFTAR ISI}

Kata Pengantar...

$\mathrm{V}$

Suryadiputra Liawatimena; Andy Margono; Yati

Analisis Strategi Pemasaran Web Hosting PT Singcat Network

(Strategic Analysis of Web Hosting Marketing on Singcat Network Company)

Budiman Notoatmojo; Haryadi Sarjono

Analisis Program Pengembangan Agrobisnis Holtikultura dengan Metode Policy Analysis Matrix (Development Program Analysis of Horticulture Agribusiness

Using Policy Analysis Matrix Method).

Agustina Tutik; Synthia Atas Sari; Hartiwi Prabowo

Perancangan Model Evaluasi Diri Dosen

(A Model Design of Lecturer Personal Evaluation)

\section{Henny Hendarti}

Peranan Biaya Sosial dalam Meningkatkan Kinerja Sosial dan

Kinerja Keuangan Perusahaan High dan Low Profile

(The Role of Social Cost in Inceasing the Social and

Financial Performances of High and Low Profile Companies).

Dyah Budiastuti; Diananda Gf

Analisis Tingkat Kepentingan Desain Industri Produk Handphone:

Studi Kasus di Fakultas Ekonomi UBiNus

(The Importance Level Analysis of Handphone Product Industry Design:

A Case Study on Faculty of Economics on Bina Nusantara University)

\section{Endang Ernawati}

Manajemen Literatur Kelabu sebagai Pendukung Penelitian dan Penulisan Karya Ilmiah

(Grey Literature Management for Supporting Research and Scientific Writing Activities)

\section{Dedi Walujadi}

Potensi dan Prospek Industri Kecil

(Potency and Prospect of Small Scale Industry). 